\title{
Characterization of transposon insertion mutants of Methylobacterium extorquens AM1 (Methylobacterium strain AM1) which are defective in methanol oxidation
}

\author{
KIM ENG LeE ${ }^{1}$, S. Stone ${ }^{2}$, P. M. Goodwin ${ }^{2 *} \dagger$ and B. W. HollowaY ${ }^{1}$ \\ ${ }^{1}$ Department of Genetics and Developmental Biology, Monash University, Clayton, Victoria 3168, Australia \\ ${ }^{2}$ School of Cell and Molecular Biology, North East Surrey College of Technology, Epsom, Surrey KT17 3DS, UK
}

(Received 29 August 1990; revised 26 November 1990; accepted 10 December 1990)

\begin{abstract}
Three previously reported Tn 5 mutants of Methylobacterium extorquens AM1, Cou-1, Cou-3 and Cou-6, which are able to grow on methylamine but not methanol, were characterized by biochemical analyses and complementation tests using two genomic libraries of $M$. extorquens AM1. We have designated the genes defective in these mutants as cou-1, cou-3 and cou-6 and mapped the site of $\mathrm{Tn} 5$ insertion in each. Biochemical results showed that two of these methanol oxidation (Mox) mutants, Cou-1 and Cou-3, are phenotypically similar to the previously identified MoxE class of mutant while Cou- 6 resembled the MoxD class. Complementation tests and mapping the site of the $\mathrm{Tn} 5$ insertions indicated that cou- 1 is another Mox gene linked to mox $E$ and that cou- 6 is linked to moxD. The Tn 5 insertion in cou-3 mapped within the mox $J$ gene and therefore is the first detected mutation of the mox $J$ gene which was identified from expression studies. A MoxE mutant of $M$. extorquens AM1 was complemented by two different cosmid clones; one carried the moxE gene and the other contained two mox gene clusters, moxFJGI and mox $A K L B$. Hybridization experiments indicated that the moxE gene was not present on this latter clone, and it must therefore encode a gene capable of suppressing a MoxE mutation.
\end{abstract}

\section{Introduction}

Methylobacterium extorquens AM1 is a pink-pigmented facultative methylotroph which is able to grow on reduced $\mathrm{C}_{1}$ compounds such as methanol and methylamine as well as on multicarbon compounds, including ethanol and succinate. Methanol and ethanol are oxidized by methanol dehydrogenase, a periplasmic quinoprotein which is composed of two alpha subunits $(60 \mathrm{kDa})$ and two beta subunits $(8.4 \mathrm{kDa})$ arranged in an alpha $_{2}$ beta $_{2}$ configuration (Nunn et al., 1989). Two molecules of pyrroloquinoline quinone (PQQ) are bound non-covalently to each enzyme molecule. There is evidence that electrons are transferred from methanol dehydrogenase to cytochrome $c_{\mathrm{L}}$, an unusual $c$-type cytochrome which is specifically involved in methanol oxidation (see Anthony, 1986). M. extorquens AM1 contains a second $c$-type cytochrome $\left(c_{\mathrm{H}}\right)$, which may be involved in electron transport from methanol and/or

\footnotetext{
$\dagger$ Present address: The Wellcome Trust, 1 Park Square West London NW1 4LJ, UK.

Abbreviation: $\mathrm{PQQ}$, pyrroloquinoline quinone.
}

methylamine (Beardmore-Gray et al., 1983; Fukumori \& Yamanaka, 1987).

Following investigations of the biochemistry and genetics of mutants of $M$. extorquens AM1 and $M$. organophilum which were unable to oxidize methanol, Lidstrom and coworkers identified and partially mapped at least 17 genes (mox genes) which are involved in methanol oxidation (Nunn \& Lidstrom, 1986a, b; Anderson \& Lidstrom, 1988; Nunn et al., 1989; Lidstrom \& Stirling, 1990). The mox $F$ and moxI genes which encode the alpha and beta subunits of methanol dehydrogenase are closely linked to mox $G$, the structural gene for cytochrome $c_{\mathrm{L}}$, and moxJ, which encodes a 30 $\mathrm{kDa}$ protein of unknown function. These genes are arranged in the order $\left(5^{\prime}\right.$ to $\left.3^{\prime}\right)$ moxFJGI. Three genes $\operatorname{mox} A, K$ and $L$ (formerly mox $A 1, \operatorname{mox} A 2$ and $\operatorname{mox} A 3$ ) which are closely linked to each other, are thought to be required for the association of PQQ with methanol dehydrogenase. These three genes are linked to $\operatorname{mox} B$, a putative regulatory gene. Another six genes, $\operatorname{mox} C, P, O$, $M, N$ and $D$, are closely linked; three $(\operatorname{mox} C, P$ and $O$ ) are required for $\mathrm{PQQ}$ synthesis and the rest have unknown functions. Another gene, moxH, is unlinked to 
this cluster, but is also necessary for PQQ synthesis. A final mox region contains a further two genes of unknown function, mox $E$ and $Q$.

The mutants used by Nunn $\&$ Lidstrom $(1986 a, b)$ were isolated using UV and chemical mutagenesis. In this paper we describe the biochemical characterization of three Tn5 insertion mutants of $M$. extorquens AM1 which are defective in methanol oxidation. We have mapped the site of the Tn 5 insertion in each one and complemented them using cosmid clones from two genomic libraries. Our results demonstrate that one of the mutants is defective in the moxJ gene. The second is probably mutated in $\operatorname{moxN}$ and the third may have a lesion in $\operatorname{mox} Q$.

\section{Methods}

Bacterial strains. The bacterial strains and plasmids used in this study are shown in Table 1.

Growth of organisms. M. extorquens AM1 was grown on MacLennan's medium as described by Tatra \& Goodwin (1983). Escherichia coli strains were grown in either LB medium (Maniatis et al., 1982) or minimal medium (Vogel \& Bonner, 1956). Strains carrying plasmids and/or transposons were grown in the presence of the appropriate antibiotics.

Antibiotics in the growth medium were used at the following final concentrations: oxytetracycline hydrochloride (Sigma), $20 \mu \mathrm{g} \mathrm{ml}^{-1}$ for E. coli, $10 \mu \mathrm{g} \mathrm{ml}^{-1}$ for $M$. extorquens $\mathrm{AM} 1$; kanamycin sulphate (Sigma), $100 \mu \mathrm{g} \mathrm{ml}^{-1}$ for $M$. extorquens AM1, $20 \mu \mathrm{g} \mathrm{ml}^{-1}$ in LB medium and $50 \mu \mathrm{g} \mathrm{ml}^{-1}$ in minimal medium for $E$. coli.

Enzyme assays. Bacteria were grown on media containing methanol and methylamine as carbon sources in order to induce methanol dehydrogenase to maximum levels. Cell extracts were prepared as described by Tatra \& Goodwin (1985); methanol dehydrogenase was assayed by the method of Dunstan et al. (1972) as modified by Tatra \& Goodwin (1985).

Partial purification of c cytochromes. Crude extracts were acid treated, then passed down a DEAE-cellulose column to separate cytochromes $c_{\mathrm{H}}$ and $c_{\mathrm{L}}$ as described by O'Keeffe \& Anthony (1980); the resulting fractions were scanned for the presence of reduced cytochrome $c$ after the addition of sodium dithionite.

SDS gel electrophoresis. Whole cells (approx. $500 \mu \mathrm{g}$ wet weight), grown on medium containing methanol and methylamine, were boiled for $5 \mathrm{~min}$ with sample buffer and then electrophoresed on SDS polyacrylamide gels (Laemmli, 1970).

Western blotting. Duplicate samples of lysed whole cells were electrophoresed on a $12 \%(w / v)$ SDS polyacrylamide gel. One set of duplicate samples was stained with PAGE-blue and the other set was blotted onto a Hybond nylon membrane as described by Nunn \& Lidstrom $(1986 a)$. The blot was then incubated with antibody raised against purified methanol dehydrogenase prepared as described by Nunn \& Lidstrom (1986a) (this was a gift from D. Nunn). Bound antibody was detected using the Bio-Rad Immunoblot GAR-HPR assay. Lysates of wild-type $M$. extorquens AMI were used as a positive control; a lysate of $E$. coli was used as a negative control to check that in our system the methanol dehydrogenase antibody preparation did not cross-react with a $58 \mathrm{kDa}$ protein (the Gram-negative 'common antigen') which is found in many Gram-negative bacteria and can be confused with methanol dehydrogenase (Nunn \& Lidstrom, 1986b). We did not detect this protein in our experiments.

Haem stain. Samples of lysed whole cells were electrophoresed on a $15 \%$ SDS polyacrylamide gel, then cytochromes were detected using $o$ dianisidine, as described by Francis \& Becker (1984). After photography of the haem stain the gel was stained with PAGE-blue.

Complementation of $C_{1}$-negative mutants of $M$. extorquens $A M 1$. Two genomic libraries of $M$. extorquens AMl were used. One was constructed by cloning fragments from a partial Sau $3 \mathrm{~A}$ digest of $M$. extorquens AM1 chromosomal DNA into the BgIII site of cosmid vector pLA2917. The recombinant DNA was packaged into $\lambda$ heads and then introduced into $E$. coli S17-1. Complementation tests were carried out as described by Lyon et al. (1988) on MacLennan's minimal medium supplemented with methanol and tetracycline.

The HindIII library constructed by Fulton et al. (1984) in cosmid vector pVK 100 was also used. E. coli $\mathrm{HB} 101$ was the host for this library and triparental matings were performed as described by Stone \& Goodwin (1989).

For complementation of MoxD and MoxE mutants, two different strains carrying each mutation were used. UV9 (MoxD) and AA31 (MoxE) were used with the Sau3A bank. Complementation by the HindIII library was carried out with UV27 (MoxD) and AA32 (MoxE).

DNA manipulation and isolation. $M$. extorquens AMI chromosomal DNA was prepared by the methods of Scott et al. (1981) and Fulton $e t$ al. (1984). Large-scale plasmid DNA extractions from E. coli were done as described by Nayudu \& Holloway (1981). Rapid plasmid extractions were carried out using the boiling method described in Maniatis et al. (1982). Transformation of plasmid DNA was performed according to Maniatis et al. (1982) using competent cells prepared by the method of Cohen et al. (1972). Restriction enzymes were obtained from Promega Biotec and used according to the manufacturer's instructions.

Agarose gel electrophoresis was performed using $0.7 \%$ agarose in Tris/acetate buffer (Maniatis et al., 1982). DNA fragments used for hybridization and subcloning were purified from low-melting-temperature agarose gels as in Maniatis et al. (1982).

DNA-DNA hybridizations. DNA was transferred from agarose gels to Hybond-N nylon membranes (Amersham) by the method of Smith \& Summers (1980). DNA preparations used as probes were nicktranslated according to the method of Rigby et al. (1977). The blots were treated in $50 \%(\mathrm{v} / \mathrm{v})$ formamide, $4 \times \mathrm{SSPE}$ (Maniatis et al., 1982), $0.1 \%(\mathrm{w} / \mathrm{v})$ SDS, $0.5 \%(\mathrm{v} / \mathrm{v})$ Blotto $(10 \%$, w/v, skim milk powder plus $0.2 \%$, w/v, sodium azide) and $50 \mu \mathrm{g} \mathrm{ml}^{-1}$ of denatured herring sperm DNA for $2 \mathrm{~h}$ at $37^{\circ} \mathrm{C}$ prior to the addition of nick-translated probe. Hybridization was carried out at $37^{\circ} \mathrm{C}$ for $24 \mathrm{~h}$. The blots were then washed twice in $2 \times$ SSC (Maniatis et al., 1982), $0.1 \%$ SDS at $65^{\circ} \mathrm{C}$ for a total of $40 \mathrm{~min}$. Another wash of higher stringency was performed in $0.1 \times \mathrm{SSC}, 0.1 \% \mathrm{SDS}$ at $65^{\circ} \mathrm{C}$ for $20 \mathrm{~min}$. Autoradiography of the blots was done at $-70^{\circ} \mathrm{C}$ for $12-24 \mathrm{~h}$.

$T n 5$ mutagenesis of pMO1917. The plasmid was transferred from $E$. coli $\mathrm{S} 17-1$ into $E$. coli $\mathrm{CZ1}$, which harbours $\mathrm{Tn} 5$, by delayed patch mating on $\mathrm{LB}$ medium for $4 \mathrm{~h}$ at $37^{\circ} \mathrm{C}$ then streaking onto kanamycin and tetracycline selective medium and incubating at $37^{\circ} \mathrm{C}$ for $24 \mathrm{~h}$. Several of these $\mathrm{Km}^{\mathrm{R}} \mathrm{Tc}^{\mathrm{R}}$ exconjugants were purified and mated with E. coli $\mathrm{DH} 1$ in order to select for pMO1917 with $\mathrm{Tn} 5$ inserted. Overnight cultures of E. coli $\mathrm{CZl}(\mathrm{pMO1917)}$ and $E$. coli $\mathrm{DH} 1$ were mixed in a ratio of $2.5: 1$ and passed through a membrane filter (Gelman; $0.45 \mu \mathrm{m}$ pore size and $25 \mathrm{~mm}$ diameter). The filter was incubated on LB medium at $37^{\circ} \mathrm{C}$ for $4 \mathrm{~h}$. Cells were washed off with $1 \mathrm{ml}$ of saline and $0.2 \mathrm{ml}$ aliquots were plated onto minimal medium supplemented with $0.5 \mathrm{~mm}$-thiamin and kanamycin then incubated for $4 \mathrm{~d}$ at $37^{\circ} \mathrm{C}$. Plasmid DNA was prepared from these $\mathrm{Km}^{\mathrm{R}}$ exconju- 
Table 1. Bacterial strains and plasmids

\begin{tabular}{|c|c|c|}
\hline Strain/plasmid & Relevant properties* & Reference/source \\
\hline \multicolumn{3}{|c|}{ Methylobacterium extorquens AM1 } \\
\hline Wild-type & & Peel \& Quayle (1961) \\
\hline Cou-1 & $\operatorname{cou}-1:: \operatorname{Tn} 5$ & Whitta et al. (1985) \\
\hline Cou-3 & cou-3: : Tn 5 & Whitta et al. (1985) \\
\hline Cou-6 & $\operatorname{cou}-6:: \operatorname{Tn} 5$ & Whitta et al. (1985) \\
\hline UV27, UV9 & $\operatorname{mox} D$ & Nunn \& Lidstrom (1986a) \\
\hline AA32, AA31 & $\operatorname{mox} E$ & Nunn \& Lidstrom $(1986 a)$ \\
\hline UV10 & $\operatorname{mox} G$ & Nunn \& Lidstrom (1986a) \\
\hline \multicolumn{3}{|l|}{ Escherichia coli } \\
\hline $\mathrm{HB} 101$ & $\begin{array}{l}\mathrm{F}^{-} \text {hsdS20 (hsdR hsdM) recA13 ara-14 proA2 lacYl galK2 } \\
\text { rpsL20 xyl-5 mtl supE44 thi-1 leuB6 } \lambda^{-}\end{array}$ & $\begin{array}{l}\text { Fulton et al. (1984) } \\
\text { Boyer \& Roulland-Dussoix (1969) }\end{array}$ \\
\hline S17-1 & pro $h s d R$ hsd $M^{+}$thi rec $A(\mathrm{RP} 4-2, \mathrm{Tc}:: \mathrm{Mu}, \mathrm{Km}:: \mathrm{Tn} 7, \mathrm{Tn} l)$ & Simon et al. (1983) \\
\hline $\mathrm{CZ1}$ & his: : Tn 5 derivative of $\mathrm{S} 17-1$ & Holloway Collection \\
\hline $\mathrm{DH} 1$ & recAl endAl gyrA96 thi hsdRI7 $\left(\mathrm{r}_{\mathrm{k}}^{-} \mathrm{m}_{\mathrm{k}}^{+}\right)$supE44 relA $\lambda^{-} \mathrm{F}^{-}$ & Hanahan (1983) \\
\hline \multicolumn{3}{|l|}{ Plasmids } \\
\hline pVK 100 & $\operatorname{Tc}^{r} \mathrm{Km}^{\mathrm{r}} \cos$ & Knauf \& Nester (1982) \\
\hline pRK2013 & $\mathrm{Km}^{\mathrm{r}}$ ColE1 replicon & Figurski \& Helinski (1979) \\
\hline pLA2917 & $\mathrm{Km}^{\mathrm{r}} \mathrm{Tc}^{\mathrm{r}} \cos$ & Allen \& Hanson (1985) \\
\hline pRK310 & Tc lacPOZ & Ditta et al. (1985) \\
\hline pMO120836 & $\begin{array}{l}\text { Ccou-3 CmoxF CmoxG CmoxA CmoxK CmoxL CmoxB } \\
C \operatorname{mox} E \mathrm{Tc}^{\mathrm{R}} \cos \end{array}$ & This paper \\
\hline pMO121511 & $C \operatorname{mox} C$ CmoxD Ccou-6 $\mathrm{Tc}^{\mathrm{R}} \cos$ & This paper \\
\hline pMO122004 & $C \operatorname{mox} E \mathrm{Tc}^{\mathrm{R}} \cos$ & This paper \\
\hline pMO1917 & $\begin{array}{l}\text { Ccou-6 } C \operatorname{mox} D \mathrm{Tc}^{\mathrm{R}}, 6.65 \mathrm{~kb} \text { HindIII-PstI fragment of } \\
\text { pMO121511 }\end{array}$ & This paper \\
\hline pMO1918 & $\underset{\mathrm{pMO} 121511}{C \operatorname{mox} D \mathrm{Tc}^{\mathrm{R}}, 4.0 \mathrm{~kb}} \operatorname{HindIII-Bam\mathrm {HI}}$ fragment of & This paper \\
\hline pMO1919 & $\begin{array}{l}2.65 \mathrm{~kb} \text { Bam HI }- \text { PstI fragment of pMO121511 sub-cloned } \\
\text { into pRK310, Tc }\end{array}$ & This paper \\
\hline pHIN-E & $C \operatorname{mox} E C \operatorname{cou}-1 \mathrm{Tc}^{\mathrm{R}} \cos$ & Nunn \& Lidstrom (1986a) \\
\hline pHIN-FG & $C \operatorname{mox} F$ CmoxG Ccou-3 $\mathrm{Tc}^{\mathrm{R}} \cos$ & Nunn \& Lidstrom $(1986 a)$ \\
\hline pHIN-D & $C \operatorname{mox} D C \operatorname{cou}-6 \mathrm{Tc}^{\mathrm{R}} \cos$ & Nunn \& Lidstrom (1986a) \\
\hline pORF9 & $0.85 \mathrm{~kb} E c o \mathrm{RI}-B a m \mathrm{HI}$ fragment of $\operatorname{mox} F$ gene & Nunn \& Lidstrom $(1986 a)$ \\
\hline pYK 310 & $0.90 \mathrm{~kb}$ Pst I-BamHI fragment of moxA gene & Kim \& Lidstrom (1989) \\
\hline pYK 340 & $1.86 \mathrm{~kb}$ Sall fragment of mox $L$ gene & M. Lidstrom (unpublished) \\
\hline
\end{tabular}

* To denote complementation, we have used the nomenclature described in Moore et al. (1983) by putting the prefix $C$ (for complementation) followed by the gene symbol of the $M$. extorquens AM 1 mutant that was complemented by the particular clone.

gants by the boiling method and then used to transform competent $E$. coli $\mathrm{S} 17-1$ by selecting for kanamycin resistance. Exconjugants were picked and grown in microtitre trays and screened for their abilities to complement UV9 and Cou-6.

\section{Results}

\section{Biochemical analysis of Tn5 insertion mutants}

The mutants used in this study were isolated by Whitta et al. (1985) and designated Cou-1, Cou-3 and Cou-6. They are able to grow on methylamine and succinate but not on methanol or ethanol, indicating that they are all defective in methanol oxidation. Growth was not observed on methanol medium supplemented with the methanol dehydrogenase cofactor PQQ. Extracts of these mutants had no detectable methanol dehydrogen- ase activity. Furthermore, the alpha subunit of methanol dehydrogenase was not detected in cell lysates of any of the mutants when SDS polyacrylamide gel electrophoresis and Western blotting was carried out, the latter using an antibody raised against purified methanol dehydrogenase. When lysates of wild-type bacteria were used one band was observed, namely the $60 \mathrm{kDa}$ alpha subunit of methanol dehydrogenase.

Crude extracts of all three mutants contained cytochromes which eluted from DEAE-cellulose columns in the positions expected of cytochromes $c_{\mathrm{H}}$ and $c_{\mathrm{L}}$. SDS polyacrylamide gel electrophoresis of whole-cell lysates followed by staining for haem proteins confirmed the presence of cytochrome $c_{\mathrm{H}}$ but cytochrome $c_{\mathrm{L}}$ (molecular mass on SDS-polyacrylamide gels approximately 20.9 $\mathrm{kDa}$ ) was not observed in extracts of the mutants (Fig. 1). Instead a haem protein of about $23 \mathrm{kDa}$ was present in 


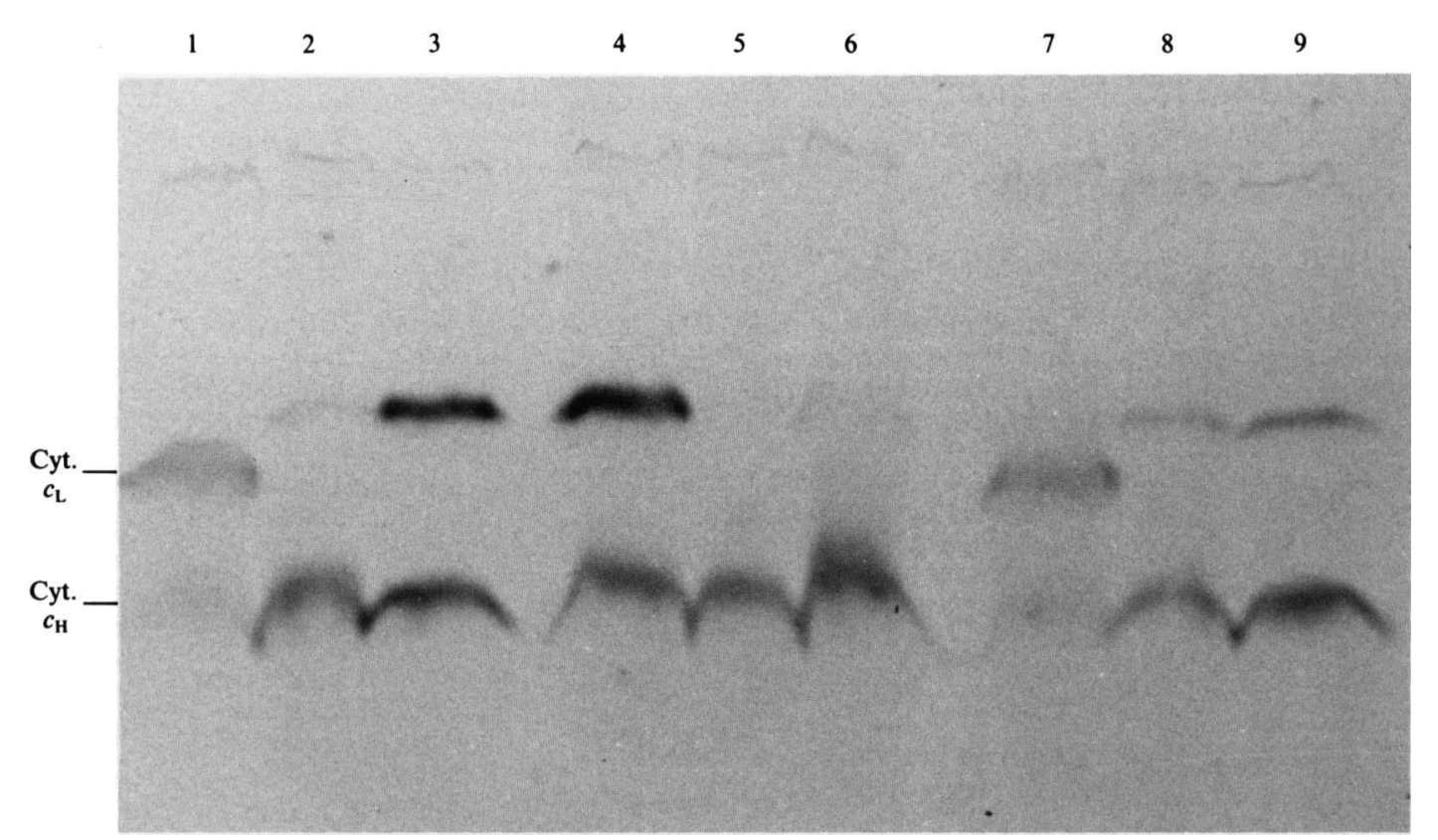

Fig. 1. SDS polyacrylamide gels showing haem staining proteins in whole-cell lysates of wild-type and mutant strains of $M$. extorquens AM1. Lanes: 1, wild-type; 2, Cou-3; 3, UV27; 4, Cou-6; 5, UV1O (a MoxG mutant); 6, Cou-3; 7, wild- type; 8, AA32; 9, Cou-1.

Table 2. Summary of biochemical phenotypes of mutants

\begin{tabular}{lccccc}
\hline \hline Mutant & $\begin{array}{c}\text { MDH } \\
\text { activity }\end{array}$ & $\begin{array}{c}\text { alpha } \\
\text { subunit }\end{array}$ & $\begin{array}{c}\text { Cyt. } \\
c_{\mathrm{L}}\end{array}$ & $\begin{array}{c}\text { Cyt. } \\
c-553\end{array}$ & $\begin{array}{c}\text { Known Mox mutant of } \\
\text { similar phenotype }\end{array}$ \\
\hline Cou-1 & - & - & - & + & MoxE \\
Cou-3 & - & - & - & + & MoxE \\
Cou-6 & - & - & - & +++ & MoxD \\
\hline \hline
\end{tabular}

MDH, methanol dehydrogenase.

small amounts in Cou- 1 and Cou- 3 and in larger amounts in Cou-6. We also observed this $23 \mathrm{kDa}$ cytochrome in large amounts in UV27, a MoxD mutant, and in trace amounts in AA32, a MoxE mutant, confirming the results of Nunn \& Lidstrom (1986b). Day et al. (1990) have recently shown that the $23 \mathrm{kDa}$ cytochrome, designated cytochrome $c$-553, is a novel $c$-type cytochrome which has no structural relationship to cytochrome $c_{\mathrm{L}}$. Its function is unknown. Thus phenotypically Cou-1 and $\mathrm{Cou}-3$ resemble the MoxE class of mutants and Cou6 the MoxD class. These results are summarized in Table 2.

\section{Tn5 mapping and complementation tests}

Individual clones from HindIII and Sau3A gene libraries of $M$. extorquens AM1 DNA known to complement previously characterized Mox mutants were tested for their ability to complement Cou-1, Cou-3 and Cou-6, with previously characterized MoxD and E mutants being included as controls (Table 3).

(i) Cou-1. Cou-1 and a MoxE mutant, AA32, were found to be biochemically similar according to the tests performed on them. They were both complemented by the same clone from the HindIII library, namely pHINE. This plasmid carries a $7.6 \mathrm{~kb}$ HindIII fragment known as HINDIII-E. Another MoxE mutant, AA31, was complemented by two clones from the Sau3A library, pMO122004 and pMO120836. The latter also complemented mutants of the MoxA, K, L, B, F and G classes. However, Cou-1 was not complemented by either pMO122004 or pMO120836, suggesting that Cou-1 does not have a defect in the moxE gene.

As these results indicate that the defects in Cou- 1 and mox $E$ are linked on HINDIII-E, this fragment was isolated from pHIN-E and used to probe chromosomal 
Table 3. Complementation of Cou and Mox mutants

\begin{tabular}{lccccccc}
\hline \hline & \multicolumn{8}{c}{ Mutants: } \\
\cline { 2 - 7 } & & & \multicolumn{9}{c}{ MoxE class } \\
\cline { 2 - 8 } \multicolumn{1}{c}{$\begin{array}{c}\text { Cosmid } \\
\text { clones }\end{array}$} & Cou-1 & Cou-3 & AA31 & AA32 & Cou-6 & UV9 & UV27 \\
\hline pMO120836* & - & + & + & ND & - & - & ND \\
pHIN-FG & - & + & ND & - & - & ND & - \\
pMO122004 & - & - & + & ND & - & - & ND \\
pHIN-E & + & - & ND & + & - & ND & - \\
pMO121511 & - & - & - & ND & + & + & ND \\
pMO1917 & ND & ND & ND & ND & + & + & ND \\
pMO1918 & ND & ND & ND & ND & - & + & ND \\
pMO1919 & ND & ND & ND & ND & - & - & ND \\
pHIN-D & - & - & ND & - & + & ND & + \\
\hline \hline
\end{tabular}

ND, Not done

* This clone is also able to complement mutants defective in $\operatorname{mox} A, K, L, B, F$ and $G$.

$\dagger$ This clone is also capable of complementing a mutation in mox $C$.

digests of Cou-1, wild-type $M$. extorquens AM1 and digests of the cosmids pMO120836 and pMO122004. As shown in Fig. 2, the HINDIII-E fragment hybridized to a $7.6 \mathrm{~kb}$ HindIII fragment of the wild type DNA (lane 2) and to two HindIII fragments of Cou-1 (lane 5), confirming that the $\operatorname{Tn} 5$ insertion in Cou- 1 was within HINDIII-E. Consideration of the results of probing BamHI and BamHI/HindIII digests of Cou-1 and wildtype DNA with HINDIII-E indicated that the Tn5 insertion in Cou-1 mapped within $0.4 \mathrm{~kb}$ of the HindIII site of HINDIII-E (Fig. 3c). In contrast, Nunn \& Lidstrom (1986a) mapped the moxE gene to about $2 \mathrm{~kb}$ from the same site. Furthermore the HINDIII-E probe hybridized to a $7.5 \mathrm{~kb}$ HindIII fragment of pMO122004 (Fig. 2, lane 11, fragment arrowed). Approximately $0.37 \mathrm{~kb}$ of this $7.5 \mathrm{~kb}$ fragment was vector DNA and thus only about $7.13 \mathrm{~kb}$ of HINDIII-E was present in pMO122004; the remaining $0.47 \mathrm{~kb}$ of HINDIII-E must therefore contain at least part of the gene which complements Cou-1.

Even though a MoxE mutant, AA31, was complemented by pMO120836, we could not demonstrate any homology between the chromosomal insert of pMO120836 and HINDIII-E (Fig. 2, lanes 8-10). Hybridization was observed between the HINDIII-E probe and the largest fragment of pMO120836, which is mainly vector DNA. However, since this probe also has homology with the large fragment of pMO122004 (lanes 11-13), the hybridization can be attributed to contamination of the HINDIII-E fragment by DNA from the vector, pVK 100, which, like pLA2917, is derived from plasmid RK2.

When labelled pMO120836 was used to probe a HindIII digest of wild-type $M$. extorquens AM1 DNA, homology was shown with three chromosomal frag- ments, none of which corresponded to HINDIII-E (Fig. 4, lane 2). The largest fragment to which pMO120836 hybridized was HINDIII-AB (which carries the moxA, $K, L$ and $B$ genes) and the smallest was HINDIII-FG (which carries the $\operatorname{mox} F, J, G$ and $I$ genes). The other chromosomal fragment was about $11.6 \mathrm{~kb}$, whereas HINDIII-E is only $7.6 \mathrm{~kb}$. In addition we have shown that pMOI20836 carried the HINDIII-FG fragment and part of the HINDIII-AB fragment (Fig. $3 a ; \mathrm{H}_{1}$ to $\mathrm{H}_{2}$ and $\mathrm{H}_{2}$ to $\mathrm{H}_{3}$ respectively) by probing with clones carrying moxF (pORF9), mox $A$ (pYK310) and moxL (pYK 340) (data not shown). These three clones were kindly provided by $\mathrm{Dr} \mathrm{M}$. Lidstrom. Therefore complementation of AA31 by pMO120836 could not be due to the presence of the mox $E$ gene on this cosmid and it must contain a gene which is capable of suppressing the MoxE mutation.

(ii) Cou-3. Although its biochemical characteristics were similar to the MoxE group of mutants, Cou-3 was complemented by pHIN-FG from the HindIII gene library and by pMO120836 from the Sau3A gene library. As shown in Fig. 3(a), pMO120836 consists of the HINDIII-FG region, which is flanked by part of HINDIII-AB on its right and part of an unknown $11.6 \mathrm{~kb}$ HindIII fragment on its left. Comparison of the HindIII digests of wild-type $M$. extorquens AM1 and Cou-3 after probing with pMO120836 (Fig. 4, lanes 2 and 5 ), showed that in Cou- $3 \mathrm{Tn} 5$ is present on the HINDIIIFG fragment. The insert was located about $1.3 \mathrm{~kb}$ upstream from the $\mathrm{BamHI}_{2}$ site of HINDIII-FG as indicated in Fig. 3(a). Hence, the insertion is in the middle of the $1.0 \mathrm{~kb} \mathrm{XhoI} \mathrm{I}_{2}-\mathrm{XhoI}_{3}$ fragment. Anderson \& Lidstrom (1988) have shown that the region from the $X h o I_{1}$ site to the BamHI ${ }_{2}$ site of HINDIII-FG codes for 


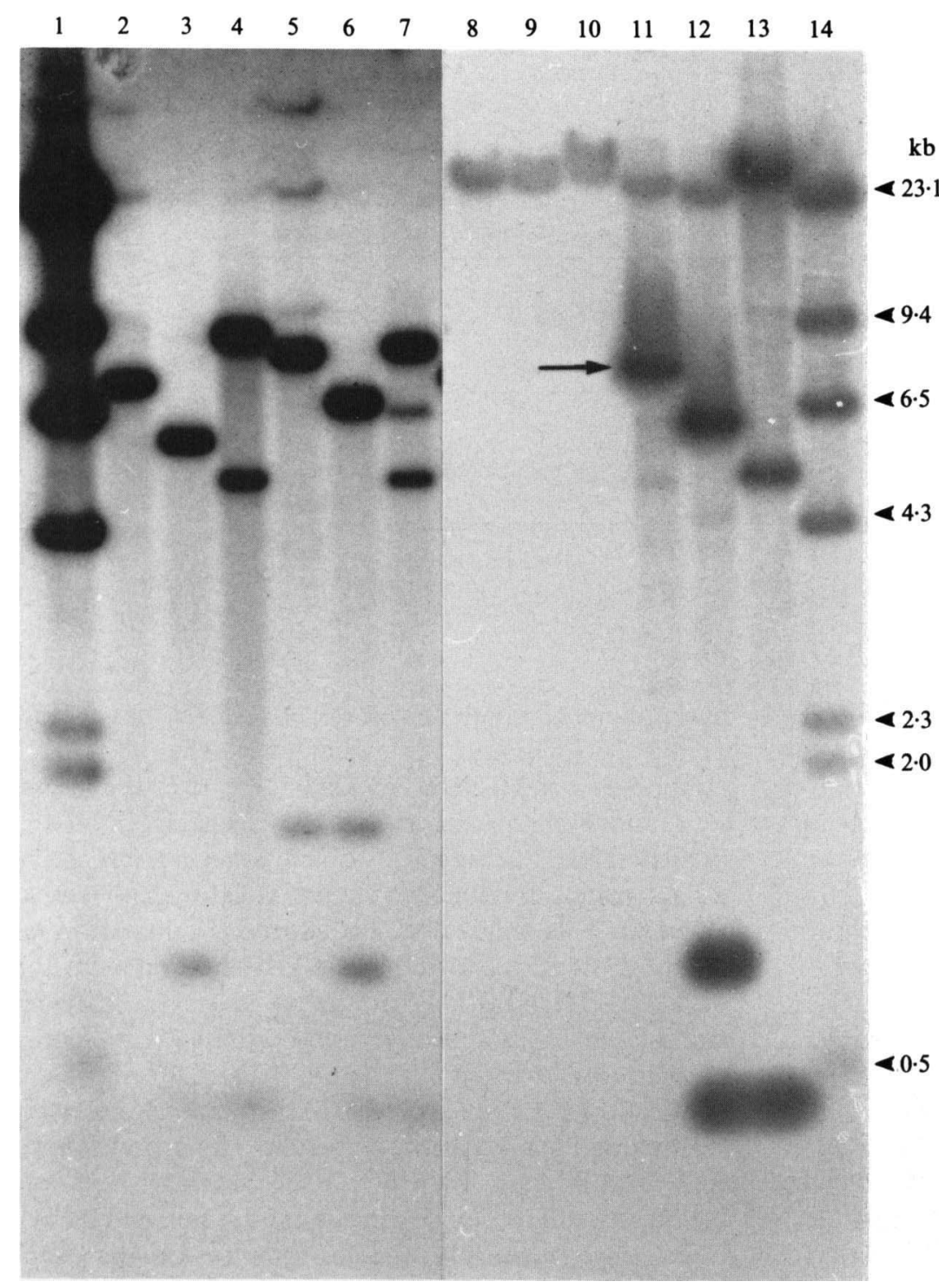

Fig. 2. Hybridization of the HINDIII-E probe to restriction enzyme digests of wild-type $M$. extorquens AMI genomic DNA, Cou-1 genomic DNA, pMO120836 and pMO122004. Lanes 1 and 14 contain $\lambda$ HindIII fragments used as size standards. The other lanes are (i) HindIII-digested wild-type $M$. extorquens AMI (lane 2), Cou-1 (lane 5), pMO120836 (lane 8) and pMO122004 (lane 11); (ii) HindIII- and Bam HI-digested wild-type $M$. extorquens AMI (lane 3), Cou-1 (lane 6), pMO120836 (lane 9) and pMO122004 (lane 12); (iii) BamHI-digested wildtype $M$. extorquens AMI (lane 4), Cou-1 (lane 7), pMO120836 (lane 10) and pMO122004 (lane 13).

four polypeptides which are the products of the $\operatorname{mox} F, J$, $G$ and $I$ genes. Part of the mox $J$ gene, which encodes a 30 $\mathrm{kDa}$ protein of unknown function, extends into the $1.0 \mathrm{~kb} \mathrm{XhoI}{ }_{2}-\mathrm{XhoI}_{3}$ fragment. DNA sequence analysis by Nunn \& Anthony (1989) and Anderson et al. (1990) has shown that the end of moxJ is 865 bases from the $X h o \mathrm{I}_{2}$ site, i.e. about 329 bases after the Tn 5 insertion in Cou-3. Thus, the Tn5 insertion in Cou-3, which resembles MoxE-type mutants biochemically, is the first reported mutation of the moxJ gene.

(iii) Cou-6. The mutant Cou-6 resembled the MoxD group of mutants phenotypically and both mutants were complemented by the same clones from the Sau3A library (pMO121511: see Table 3 and Fig. $3 d$ ) and the HindIII library (pHIN-D). Nunn \& Lidstrom (1986a) generated a Tn5 marker exchange mutation which indicated that moxD mapped $1.6 \mathrm{~kb}$ to the left of the $B a m H_{1}$ site of HINDIII-D. To map the Tn 5 insertion of Cou-6, digests of wild-type $M$. extorquens AM1 and Cou6 DNA were probed with pMO121511. The results are shown in Fig. 5. The Tn5 insertion was not on the $4.0 \mathrm{~kb}$ HindIII-BamHI fragment to which moxD mapped but was on the $2.65 \mathrm{~kb}$ Bam HI-Pst I fragment which lies next to it (see Fig. $3 d$ ). The insertion is $0.22 \mathrm{~kb}$ to the right of this BamHI site. The HindIII-PstI, HindIII-BamHI and BamHI-Pst I fragments of the $6.65 \mathrm{~kb}$ HindIII-Pst I fragment were subcloned into pRK 310 . The abilities of those subcloned fragments to complement UV9 and Cou-6 are summarized in Table 3 . The $6.65 \mathrm{~kb}$ HindIIIPstI fragment (pMO1917) complemented both UV9 and Cou-6. However, the $4.0 \mathrm{~kb}$ HindIII-BamI fragment 


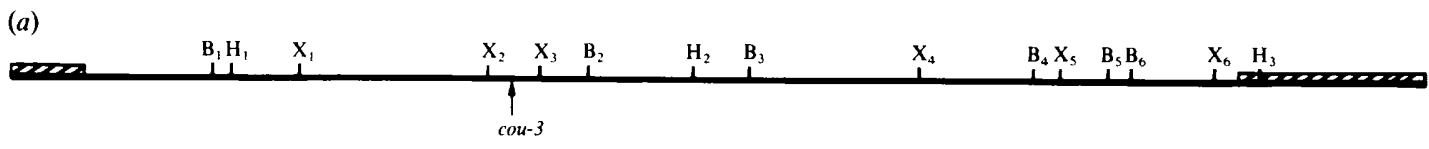

(b)

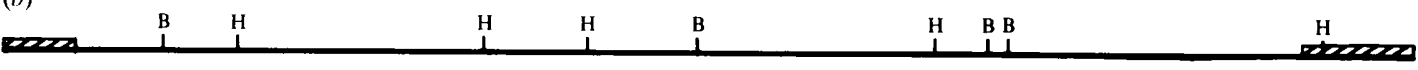

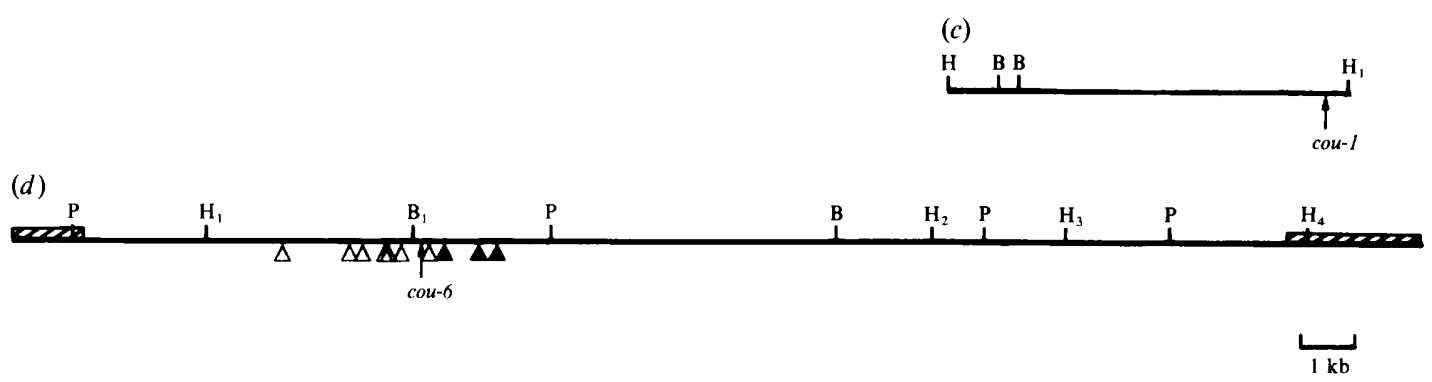

Fig. 3. Restriction enzyme maps of cosmid clones: (a) pMO120836, (b) pMO122004, (c) pHIN-E and (d) pMO121511. Chromosomal Tn 5 insertions, i.e. the insertions in the Cou mutants, are indicated by arrows. Tn 5 insertions into the HindIII-PstI subclone of pMO12511, pMO1917, which prevent complementation are represented by open triangles. Insertions which allow complementation are indicated by solid triangles. The hatched region represents vector DNA. B, BamHI; H, HindIII; P, PstI; X, Xhol. On pMO120836, $\mathrm{H}_{1}-\mathrm{H}_{2}$ represents the HINDIII-FG region, and on pMO121511 $\mathrm{H}_{1}-\mathrm{H}_{2}$ represents the HINDIII-D region.

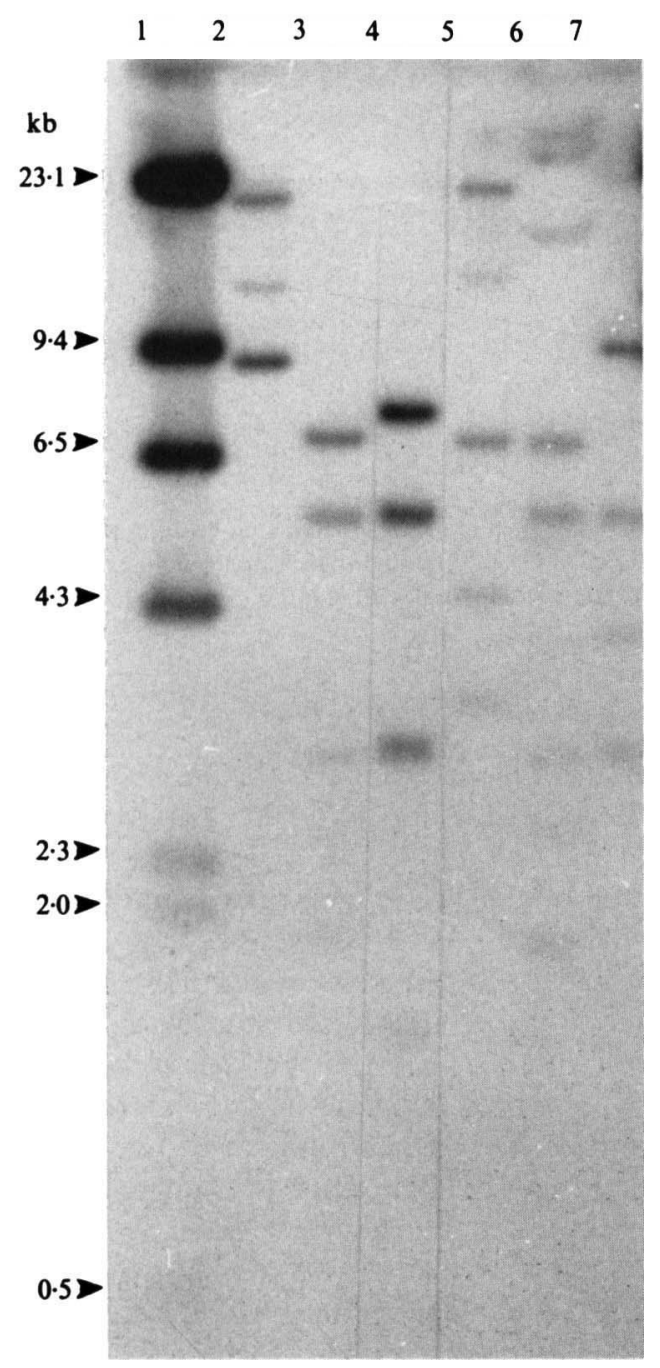

(pMO1918) complemented UV9 but not Cou-6, suggesting that the mutants are different. The gene defective in Cou-6 has a BamHI site in it, as shown by the absence of complementation of Cou- 6 by the $2.65 \mathrm{~kb} \mathrm{BamHI}-$ Pst I fragment (pMO1919), although this result could also be explained if an upstream region necessary for expression of cou-6 is missing from this fragment. Tn 5 insertions in the $6.65 \mathrm{~kb}$ HindIII-Pst Iragment are shown in Fig. $3(d)$. Insertions covering $2.8 \mathrm{~kb}$ of DNA were unable to complement either UV9 or Cou-6. Over 1000 pMO1917::Tn5 isolates were screened; none was observed to complement one mutant but not the other. A complicating factor in complementation tests involving Cou-6 may have been recombination between $\operatorname{Tn} 5$ elements on the pMO1917::Tn5 isolates and the Tn5 inserted into the chromosome of the Cou- 6 region. However, positive complementation was observed for both the Tn 5 mutant Cou- 6 and the UV-induced mutant UV9. Thus it can be concluded that cou- 6 extends at least as far as the BamHI-PstI fragment (see Fig. 3d).

Fig. 4. Hybridization of pMO120836 probe to restriction enzyme digests of wild-type $M$. extorquens AM1 genomic DNA and Cou-3 genomic DNA. Lane 1 contains $\lambda$ HindIII fragments used as size standards. The other lanes are (i) HindIII-digested wild-type $M$. extorquens AM1 (lane 2) and Cou-3 (lane 5); (ii) HindIII- and BamHIdigested wild-type $M$. extorquens AMI (lane 3) and Cou-3 (lane 6); (iii) BamHI-digested wild-type M. extorquens AMI (lane 4) and Cou-3 (lane 7). 


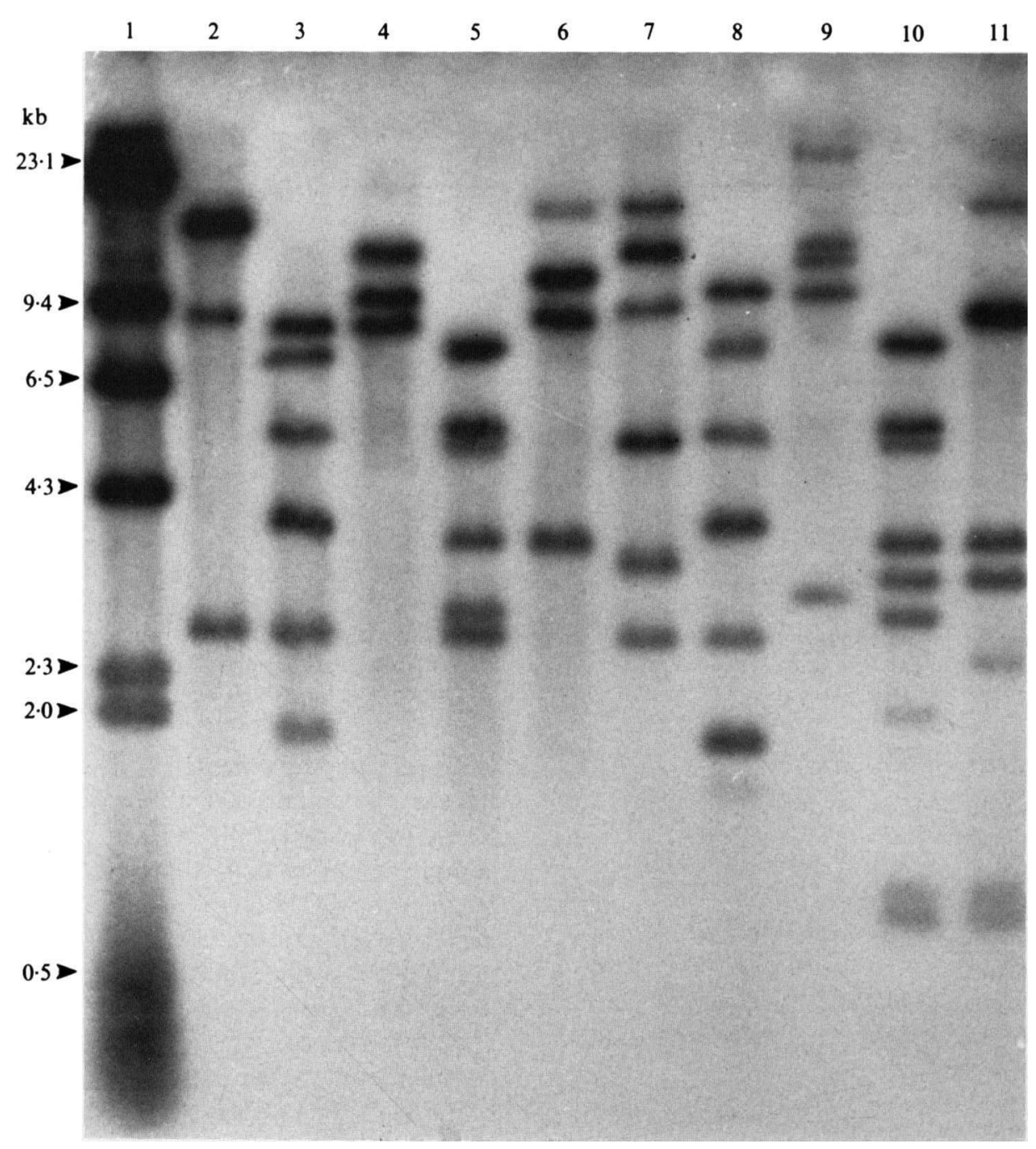

Fig. 5. Hybridization of pMO121511 probe to restriction enzyme digests of wild-type $M$. extorquens AM1 and Cou-6 genomic DNAs. Lane 1 contains $\lambda$ HindIII fragments used as size standards. Wild-type $M$. extorquens AMI was digested with HindIII (lane 2), HindIII and BamHI (lane 3), BamHI (lane 4), BamHI and PstI (lane 5) and PstI (lane 6). Cou-6 was digested with HindIII (lane 7), HindIII and BamHI (lane 8), BamHI (lane 9), BamHI and PstI (lane 10) and PstI (lane 11).

\section{Discussion}

Our study of the three Mox mutants of $M$. extorquens AM1 has shown that the mutations which they represent have not been described for $M$. extorquens AM1. The position of the mutation in Cou-3 suggests that it is a MoxJ mutant. The function of the $30 \mathrm{kDa}$ protein encoded by this gene is unknown, but since Cou-3 lacks the methanol dehydrogenase alpha subunit and cytochrome $c_{\mathrm{L}}$, it is possible that the moxJ gene product may regulate synthesis of both these proteins. However, the inability to synthesize these proteins could also be due to a polar effect of the $\mathrm{Tn} 5$ insertion in Cou- 3 on expression of $\operatorname{mox} F$ and $\operatorname{mox} G$. Indeed, it has previously been reported that $\operatorname{Tn} 5$ insertions in the maxFG region have polar effects both up- and downstream (Nunn \& Lidstrom, 1986a).

Mox mutants of the related pink-pigmented facultative methylotroph, Methylobacterium organophilum XX, have been isolated by Machlin et al. (1988). Complementation of some of these mutants with cloned $M$. extorquens AM1 DNA led to the identification of some mox genes of which there are no equivalent mutants in M. extorquens AM1 (Lidstrom \& Stirling, 1990). One such gene is mox $Q$. This gene was found to be linked to the mox $E$ equivalent of $M$. organophilum XX. cou- $I$ could be the $\operatorname{mox} Q$ equivalent in $M$. extorquens $\mathrm{AM} 1$ even though MoxQ mutants synthesize the alpha subunit of methanol dehydrogenase and cytochrome $c_{\mathrm{L}}$ (Bastien et 
al., 1989), whereas Cou-1 does not. This difference may be due to a polar effect of the $\operatorname{Tn} 5$ insertion in Cou-1 on expression of moxE.

The Tn 5 insertion in the last of these mutants, Cou- 6 , mapped close to the proposed site for the moxD gene. Complemention tests using various subclones suggest that cou-6 and moxD are separate genes. Transposon mutagenesis of the region shows that the two genes are probably co-transcribed since no $\mathrm{Tn} 5$ insertions were detected that will complement one but not the other mutant. cou- 6 maps further away from moxC, which is on the HindIII fragment to the left of HINDIII-D. Another gene, moxN , is linked to mox $D$ mutants in $M$. organophilum $\mathrm{XX}$ and there is evidence that these two genes are cotranscribed (Machlin et al., 1988; Bastien et al., 1989). Mutants of $M$. extorquens AM1 which are defective in moxN have not been described but Lidstrom \& Stirling (1990) proposed that the M. extorquens AM1 moxD gene is linked to a $\operatorname{moxN}$ gene; the order of these genes is unknown. cou- 6 may be the moxN gene of M. extorquens AM1 although Cou- 6 does not share the same phenotype as the $M$. organophilum XX Mox N mutant, which contains cytochrome $c_{\mathrm{L}}$ (Machlin et al., 1988). These differences may be due to a polar effect of the $\operatorname{Tn} 5$ insertion in Cou-6. Until the relationship of the cou genes to the mox genes can be firmly established it will be best to retain the separate gene nomenclature.

Our complementation tests have been done with two genomic libraries. This proved to be advantageous as it was observed that certain mutants could be complemented by clones from one library but not the other. This was also found to be the case with $M$. organophilum XX (Machlin et al., 1988). The Sau3A genomic library was helpful in determining linkage of some of the Mox genes. However, in our experience caution is necessary when interpreting the data from complementation tests. The complementation results using pMO120836 suggested that $\operatorname{mox} F, J, G, I$ was linked to $\operatorname{mox} A, K, L, B$ and $\operatorname{mox} E$. Linkage of $\operatorname{mox} F, G, J, I$ to $\operatorname{mox} A, K, L, B$ was verified by hybridization of pMO120836 to $M$. extorquens AM1 $\operatorname{mox} F, \operatorname{mox} A$ and $\operatorname{mox} L \mathrm{DNA}$, which yielded bands that correspond to HINDIII-FG and HINDIII-AB. However, restriction enzyme analysis and Southern hybridization showed that the moxE gene was not linked to the other genes. Hybridization results using pMO122004 and pMO120836 as probes against SpeI-digested genomic DNA of $M$. extorquens AMl separated by pulsed-field gel electrophoresis showed that they were on different SpeI fragments (data not shown). This MoxE suppressor cannot be on either HINDIII-FG or HINDIII-AB as neither fragment complemented MoxE (Nunn \& Lidstrom, 1986a). It is probable that this suppressor is located on the $11.6 \mathrm{~kb}$ HindIII fragment beside HINDIII-FG.
This work was supported by the Australian Research Council and the UK Science and Engineering Research Council.

\section{References}

ALLEN, L. N. \& HANSON, R. S. (1985). Construction of broad host range cloning vectors: identification of genes necessary for growth of Methylobacterium organophilum on methanol. Journal of Bacteriology 161, 955-962.

Anderson, D. J. \& Lidstrom, M. E. (1988). The 'mox $F G$ ' region encodes four polypeptides in the methanol-oxidizing bacterium Methylobacterium sp. strain AMI. Journal of Bacteriology 170, 22542262.

ANDERson, D. J., Morris, C. J., NunN, D. N., Anthony, C. \& Lidstrom, M. E. (1990). Nucleotide sequences of the Methylobacterium extorquens sp. strain AMI mox $F$ and $J$ genes involved in methanol oxidation. Gene 90, 173-176.

ANTHONY, C. (1986). The oxidation of methane and methanol by methylotrophs. Advances in Microbial Physiology 27, 113-210.

Bastien, C., Machlin, S., Zhang, Y., Donaldson, K. \& Hanson, R. S. (1989). Organization of genes required for the oxidation of methanol to formaldehyde in three type II methylotrophs. Applied and Environmental Microbiology 55, 3124-3130.

Beardmore-Gray, M., O'KeefFe, D. T. \& Anthony, C. (1983). The methanol:cytochrome $c$ oxidoreductase activity of methylotrophs. Journal of General Microbiology 129, 923-933.

BOYER, H. W. \& Roulland-Dussorx, D. (1969). A complementation analysis of the restriction and modification of DNA in Escherichia coli. Journal of Molecular Biology 41, 459-472.

Cohen, S. N., Chang, A. C. Y. \& Hsu, L. (1972). Non-chromosomal antibiotic resistance in bacteria: genetic transformation of Escherichia coli by R-factor DNA. Proceedings of the National Academy of Sciences of the United States of America 69, 2110-2114.

DAY, D. J., NUNN, D. N. \& ANTHONY, C. (1990). Characterisation of a novel soluble $c$-type cytochrome in a moxD mutant of Methylobacterium extorquens AM1. Journal of General Microbiology 136, 181-188.

Ditta, G., Schmidhauser, T., Yakobson, E., Lu, P., Liang, X., Finlay, D., Guiney, D. \& HeLINSKI, D. (1985). Plasmids related to the broad host range vector, pRK290, useful for gene cloning and monitoring gene expression. Plasmid 13, 149-153.

Dunstan, P. M., Drabble, W. T. \& ANTHONY, C. (1972). Microbial metabolism of $\mathrm{C}-1$ and $\mathrm{C}-2$ compounds: the involvement of glycolate in the metabolism of ethanol and of acetate by Pseudomonas AM1. Biochemical Journal 128, 99-106.

FIGURSKI, D. H. \& HELINSKI, D. R. (1979). Replication of an origincontaining derivative of plasmid $\mathrm{RK} 2$ dependent on a plasmid function provided in trans. Proceedings of the National Academy of Sciences of the United States of America 76, 1648-1652.

Francis, R. T. \& BeCKeR, R. R. (1984). Specific indication of hemoproteins in polyacrylamide gels using a double staining process. Analytical Biochemistry 136, 509-514.

FUKUMORI, Y. \& YamanAKA, T. (1987). The methylamine oxidising system of Pseudomonas AM1 reconstituted with purified components. Journal of Biochemistry 101, 441-445.

Fulton, G. L., NunN, D. N. \& Lidstrom, M. E. (1984). Molecular cloning of a malyl CoA lyase gene from Pseudomonas sp. strain AM1, a facultative methylotroph. Journal of Bacteriology 160, 718-723.

HANAHAN, D. (1983). Studies on transformation of Escherichia coli with plasmids. Journal of Molecular Biology 166, 557-580

KiM, Y. M. \& LidsTrom, M. E. (1989). Plasmid analysis in pink facultative methylotrophic bacteria using a modified acetonealkaline hydrolysis method. FEMS Microbiology Letters 60, 125-130.

KNAUF, V. C. \& Nester, E. W. (1982). Wide host range cloning vectors : cosmid clone bank of Agrobacterium Ti plasmids. Plasmid 8, $45-54$.

LAEMMLI, U. K. (1970). Cleavage of structural proteins during the assembly of the head of bacteriophage T4. Nature, London 227, 680685 . 
Lidstrom, M. \& Stirling, D. I. (1990). Methylotrophs: genetics and commercial applications. Annual Review of Microbiology 44, 27-57. Lyon, B. R., Kearney, P. P., Sinclair, M. I. \& Holloway, B. W. (1988). Comparative complementation mapping of Methylophilus spp. using cosmid gene libraries and prime plasmids. Journal of General Microbiology 134, 123-132.

Machlin, S. M., Tam, P. E., Bastien, C. A. \& Hanson, R. S. (1988) Genetic and physical analyses of Methylobacterium organophilum XX genes encoding methanol oxidation. Journal of Bacteriology 170, 141148.

Maniatis, T., Fritsch, E. F. \& Sambrook, J. (1982). Molecular Cloning, a Laboratory Manual. Cold Spring Harbor, NY : Cold Spring Harbor Laboratory.

MoORE, A. T., Nayudu, M. \& Holloway, B. W. (1983). Genetic mapping in Methylophilus methylotrophus AS1. Journal of General Microbiology 129, 785-799.

NAYUDU, M. \& Holloway, B. W. (1981). Isolation and characterization of R-plasmid variants with enhanced chromosomal mobilisation ability in Escherichia coli K12. Plasmid 6, 53-66.

NunN, D. N. \& ANTHONY, C. (1989). The nucleotide sequence and deduced amino acid sequence of the cytochrome $c_{\mathrm{L}}$ gene of Methylobacterium extorquens AM1, a novel class of $c$-type cytochrome. Biochemical Journal 256, 673-676.

NunN, D. N. \& Lidstrom, M. E. (1986a). Isolation and complementation analysis of 10 methanol oxidation mutant classes and identification of the methanol dehydrogenase structural gene of Methylobacterium sp. strain AM1. Journal of Bacteriology 166, 581590.

NunN, D. N. \& Lidstrom, M. E. (1986b). Phenotypic characterisation of 10 methanol oxidation mutant classes in Methylobacterium sp. strain AM1. Journal of Bacteriology 166, 591-597.

NunN, D. N., DAY, D. J. \& ANTHONY, C. (1989). The second subunit of methanol dehydrogenase of Methylobacterium extorquens AM1. Biochemical Journal 260, 875-862.
O'KeEFFe, D. T. \& ANThony, C. (1980). The two cytochromes $c$ in the facultative methylotroph Pseudomonas AM1. Biochemical Journal 192, 411-419.

Peel, D. \& Quayle, J. R. (1961). Microbial growth on $C_{1}$ compounds. I. Isolation and characterization of Pseudomonas AM1. Biochemical Journal 81, 465-469.

Rigby, P., Dickmann, M., Rhodes, C. \& BerG, P. (1977). Labelling DNA to high specific activity in vitro by nick translation with DNA polymerase I. Journal of Molecular Biology 113, 237-251.

ScotT, K. F., Rolfe, B. G. \& SHine, J. (1981). Biological nitrogen fixation: primary structure of the Klebsiella pneumoniae nifH and nifD genes. Journal of Molecular and Applied Genetics 1, 71-81.

Simon, R., Priefer, U. \& Puhler, A. (1983). A broad host range mobilization system for in vivo genetic engineering: transposon mutagenesis in gram negative bacteria. Bio/Technology 1, 784-791.

Smith, G. E. \& Summers, M. D. (1980). The bidirectional transfer of DNA and RNA to nitrocellulose or diazobenzyloxymethyl-paper. Analytical Biochemistry 109, 123-129.

Stone, S. \& Goodwin, P. M. (1989). Characterisation and complementation of mutants of Methylobacterium AMl which are defective in C-1 assimilation. Journal of General Microbiology 135, 227-235.

Tatra, P. K. \& Goodwin, P. M. (1983). R-plasmid mediated chromosome mobilization in the facultative methylotroph Pseudomonas AM1. Journal of General Microbiology 129, 2629-2632.

Tatra, P. K. \& Goodwin, P. M. (1985). Mapping of some genes involved in C-1 metabolism in the facultative methylotroph Methylobacterium sp. strain AMl (Pseudomonas AM1). Archives of Microbiology 143, 169-177.

Vogel, H. J. \& BonNer, D. M. (1956). Acetylornithase of Escherichia coli: partial purification and some properties. Journal of Biological Chemistry 218, 97-106.

Whitta, S., Sinclair, M. I. \& Holloway, B. W. (1985). Transposon mutagenesis in Methylobacterium AM1 (Pseudomonas AM1). Journal of General Microbiology 131, 1547-1549. 